\title{
PRODUCT FEATURES AND QUALITY IN BRAND SWITCHING BEHAVIOR OF IMPLORA EYELINER ON SUMBAWA
}

\author{
Rozzy Aprirachman ${ }^{1}$, Diah Anggeraini Hasri ${ }^{2}$ \\ ${ }^{1,2}$ Faculty of Economics and Business, Sumbawa University of Technology
}

Article DOI: https://doi.org/10.36713/epra9309 DOI No: 10.36713/epra9309

\begin{abstract}
Indonesia's economy has grown, which has led to the growth of a business. According to BPS Indonesia, there were 26 million more businesses in Indonesia in 2016. One of them is the cosmetics industry, which the minister of the industry says is important. Because there are so many different types of cosmetic industries and so much competition, manufacturers have to change their products to meet the needs of their customers. Eyeliner is a popular product in the cosmetics industry that many people use. Following the widening of Eyeliner products, many different brands came out with different levels of quality, features, and quantity, as well as other features. Consumers may switch brands because there are so many different brands for the same thing, along with their desire to find new products. Consumers look at the quality and features of a product, as well as other product attributes when they decide to switch brands. According to the results of data processing on hypothesis testing, Implora brand eyeliner has qualities and features that make people switch brands. This is based on validity, reliability, and classical assumption tests, as well as coefficients of determination. The sampling of 100 people was used in this study, which shows that product features and product quality have a big and positive impact on brand switching. According to the results of data processing on hypothesis testing, Implora brand eyeliner has qualities and features that make people switch brands.
\end{abstract}

KEYWORDS: Product Features, Product Quality, Brand Switching, and Implora Eyeliner

\section{INTRODUCTION}

Satisfaction and dissatisfaction are consumer affections, and the behavior that comes from these affections is loyalty or disloyalty to the goods or services that the person buys or services (Dwiastuti, et al 2012). Loyal behavior, also known as consumer loyalty, is when a customer is very loyal to a company's brand or product and makes a lot of repeat purchases. Loyalty is different for everyone, but there are some things that everyone agrees on it.

Loyalty isn't the only thing people do after they buy something. They also change brands. If people aren't happy with the things they bought, they might switch brands to find a better one. Besides wanting more variety and not being able to find a certain product in stores, there are other reasons why people switch brands. It's very common for people to switch brands in a lot of different markets, Debora and Yoestini (2012) say. This is especially true in markets where there are a lot of similar products at a good price. There are a lot of ways for people to buy a lot of different things at the same time (variety seeking). People often change brands when they don't like them.

They say that brand switching is a type of purchasing that involves moving from one brand to another. The reason people stop buying certain brands and start buying other brands is that they don't like them. Hawkins and Mothersbaugh (2016) say that brand switching is caused by dissatisfaction. Switching behavior is when a customer decides to stop buying things permanently or temporarily. Satisfaction is how people feel about a brand that they think is right after they buy it, or how well the product they bought does what they expect it to do. This is what Oliver (2010) says: Satisfaction is a consumer's reaction to how well a product feature or service does its job, and it's measured by how much pleasure (pleasure) the consumer gets from it. This can be both under- and over-fulfillment. Consumers are happy when the performance of a product matches what they expect. This increases the chances of them buying the same thing again.

There is a perfectly competitive market, people who like to try new things, and there are too many repeat purchases, people switch brands. In Mowen and Minor (2012), they said that the search for variety is when people buy a new brand even though they still like the old one, even though they still say they like it. Peter and Olson (2013), on the other hand, say that the need for product variety is a mental desire to buy different brands for a variety of reasons, such as new desires or boredom with the same product. 
The phenomenon of brand switching by consumers, especially Eyeliner Implora consumers in the city of Sumbawa, occurs because of the lifestyle of the Sumbawa people who like and are easily influenced by something new or something that is becoming a trend and the ability of consumers to find information about better and more products. In addition to this, the phenomenon of brand switching in the city of Sumbawa can occur due to the unavailability of the product they are looking for and then consumers look for substitute products that are considered to have the same quality or even better than the previous product. Consumers who carry out brand switching behavior are also caused by the social environment which is the benchmark for consumers in making decisions through recommendations given by their playing members. Therefore, the title that can be raised by researchers is "Product Features and Product Quality in Implora Eyeliner Brand Switching Behavior in Sumbawa City".

\section{LITERATURE REVIEW}

Because product features are closely attached to a product, including the physical form of the product or design, level of quality, durability, and ease of use. So that the more and better the features offered by the product make consumers stick with the product. However, when a product is not able to provide satisfaction with the features it offers, consumers will tend to switch or switch to using products with other brands. Research on product features, one of which was carried out by Adnyana and Semiri (2018), the results of his research stated that product features had a positive and significant effect on brand switching decisions from internet cafes to the wifi.id corner in Denpasar City. Research by Wijaya, et al (2014) also states that based on the results of data analysis, feature variables have a significant influence on brand switching decisions. Based on this description, the following research hypotheses can be proposed: H1: product features have a significant and positive effect on brand switching behavior. The ability and suitability of consumer perceptions with the quality of the products offered will assist consumers in determining attitudes in making their purchases. Consumer satisfaction and dissatisfaction with the quality of a product can lead to loyalty and can also be the cause of consumer brand switching behavior. So, product quality has an influence on consumer brand switching behavior.

From research conducted by Wahyudi, et al (2014) it is stated that based on the results of hypothesis testing, it shows that product quality has four indicators, namely product durability, attractive product packaging, Eyeliner products are good for lip health, and product diversity according to needs. has a positive and significant effect on brand switching. Similar results were also obtained from the research of Anggraeni, et al (2018) which said that product quality had a significant effect on the behavior of the Maybelline compact powder brand switching in Padang City. Meutia (2017) said that the product quality variable had a significant influence on the shift of the Oriflame brand in Langsa City. Based on this description, the following hypothesis can be proposed: $\mathrm{H} 2$ : product quality has a significant and positive effect on brand switching behavior.
Kotler and Keller (2012) in Prasetya (2016), characteristics that complement the basic functions of the product. Features are additional characteristics designed to increase consumer interest in the product or enhance the product's functionality. In this study, indicators to measure product features used indicators according to Kotler and Armstrong (2012) in Prasetya (2016), namely: diversity of features. Indicators according to Osman (2012) in Karen et al (2013) are also used for product features, namely: ease of use, satisfaction with the product, and design. In addition, indicators are also used according to Suswardji (2012) in Denty (2018), namely: size and quality of materials.

According to Kotler and Keller (2013) quality is the ability of an item to provide results or performance that match even exceeds what the customer wants. Meanwhile, according to Mowen (2012), product quality is an overall evaluation process to customers for improving the performance of a product. For this study, the indicators used to measure product quality are based on the theory of Kotler and Keller (2013), namely: form, performance quality, conformity quality, durability, reliability, and perceived quality.

\section{ANALYSIS OF THE DATA}

This research is research with the qualitative method through the associative approach. The sampling technique in this study uses Non-Probability Sampling (population unknown), namely a sampling technique that does not provide the same opportunity or opportunity to be selected as a sample (Sugiyono, 2013). The sampling method is the purposive sampling method. Purposive sampling is the determination of the sample with certain considerations. To determine the number of samples in this study, the Paul Leedy formula in Arikunto (2010) was used. The Paul Leedy model is used if the study population is a proportion or part of another population group that is larger in size. Here is the formula from Paul Leedy, namely:

$$
N=\left(\frac{Z^{2}}{e}\right)(P)(1-P)
$$

Description:

$\mathrm{N}=$ sample size

$\mathrm{Z}=$ standard score for $95 \%$ selected then the $\mathrm{Z}$ value is 1.96 (in the normal distribution table)

$e=$ proportion of sampling error $(10 \%)$

$\mathrm{P}=$ the proportion must be in the population taken $50 \%$ or 0.5

If the total population of a study is unknown, the maximum $p(1-p)$ is 0.25 , and using a $95 \%$ confidence level with a maximum error rate of $10 \%$, the sample size is:

$$
N=\left(\frac{1,96^{2}}{0,1}\right)(0,5)(1-0,5)=96,04
$$

If the questionnaire that was made was true or not, this test would show that. Valid: If the questionnaire can show something that the questionnaire will measure. In determining whether or not an item can be used, a coefficient significance test is usually done at a significance level of 0.05 . This means that an item is valid if the correlation to the total score is significant. You can use Pearson's productmoment test analysis tool to figure out how important the 
item is. Parson bivariate analysis was used for the test. It used a two-sided test with a significance level of 0.05 . The SPSS version 25 program ran a test to see if each statement in the questionnaire submitted by the researcher was true. Here are the results of that test:

\begin{tabular}{|l|c|c|c|c|}
\hline Variable & Items & r-count & r-table & Description \\
\hline Product & P1 & 0.453 & 0.361 & Valid \\
\cline { 2 - 5 } (X1) & P2 & 0.534 & 0.361 & Valid \\
\cline { 2 - 5 } & P3 & 0.593 & 0.361 & Valid \\
\cline { 2 - 5 } & P4 & 0.648 & 0.361 & Valid \\
\cline { 2 - 5 } & P5 & 0.636 & 0.361 & Valid \\
\cline { 2 - 5 } & P6 & 0.478 & 0.361 & Valid \\
\cline { 2 - 5 } & P7 & 0.580 & 0.361 & Valid \\
\cline { 2 - 5 } & P8 & 0.554 & 0.361 & Valid \\
\hline Product \\
quality & P1 & 0.693 & 0.361 & Valid \\
\cline { 2 - 5 } & P2 & 0.592 & 0.361 & Valid \\
\cline { 2 - 5 } & P3 & 0.587 & 0.361 & Valid \\
\cline { 2 - 5 } & P4 & 0.777 & 0.361 & Valid \\
\cline { 2 - 5 } & P5 & 0.734 & 0.361 & Valid \\
\cline { 2 - 5 } & P6 & 0.751 & 0.361 & Valid \\
\cline { 2 - 5 } & P7 & 0.666 & 0.361 & Valid \\
\hline Brand & P1 & 0.485 & 0.361 & Valid \\
\cline { 2 - 5 } (Y) & P2 & 0.488 & 0.361 & Valid \\
\cline { 2 - 5 } & P3 & 0.707 & 0.361 & Valid \\
\cline { 2 - 5 } & P4 & 0.708 & 0.361 & Valid \\
\cline { 2 - 5 } & P5 & 0.700 & 0.361 & Valid \\
\cline { 2 - 5 } & P6 & 0.558 & 0.361 & Valid \\
\cline { 2 - 5 } & P7 & 0.699 & 0.361 & Valid \\
\cline { 2 - 5 } & P8 & 0.708 & 0.361 & Valid \\
\hline
\end{tabular}

Source: Data processed by researchers, 2021

Based on the table above, it shows that all the instruments in this study resulted in the value of $r$-count $r$ table (0.361). So it means that all instruments in this study can be said to be valid (fit for use).

Reliability test is a term used to indicate the extent to which the measurement results are relatively consistent when the measurement is repeated two or more times. The reliability of the data in this study was tested using consistency reliability items that saw Cronbach's coefficient alpha as the coefficient of reliability. An instrument is considered reliable if it has an alpha coefficient $(\alpha)$ of 0.6 or more.

\begin{tabular}{|l|l|l|}
\hline Variable & Alpha Value & Description \\
\hline Product features & 0.674 & Reliable \\
\hline Product quality & 0.805 & Reliable \\
\hline Brand switching & 0.783 & Reliable \\
\hline
\end{tabular}

Source: Data processed by researchers, 2021

Based on the table above, it shows that the independent variables consisting of product features (x1) and product quality (x2) and the dependent variable, namely brand switching (y) each have a Cronbach's alpha value greater than 0.6. The conclusion is that the results of the test indicate that all variables in this study are reliable and can be used in further analysis.

\section{RESULTS AND DISCUSSION}

a) Normality test

The normality test in this study used the KolmogorovSmirnov Normality with the help of SPSS version 16. The results of the normality test can be seen in the following table:

\begin{tabular}{|l|l|r|}
\hline \multicolumn{2}{|c|}{ One-Sample Kolmogorov-Smirnov Test } \\
\hline \multicolumn{2}{|c|}{} & \multicolumn{1}{|c|}{ Unstandardized Residual } \\
\hline $\mathrm{N}$ & mean & 100 \\
\cline { 2 - 4 } Normal \\
Parameters & Std. & .0000000 \\
& Deviatio & \\
& $\mathrm{n}$ & \\
\hline Most & Absolute & .20292278 \\
Differences & negitive & .031 \\
\cline { 2 - 3 } & negative & -.051 \\
\hline Kolmogorov-Smirnov Z & .511 \\
\hline \multicolumn{2}{|c|}{ asymp. Sig. (2-tailed) } & .956 \\
\hline
\end{tabular}

Source: Data processed by researchers, 2021.

The results of the normality test using the KolmogorovSmirnov method showed that the significance of the normality test was 0.956 where the result was greater than the 0.05 significance level. It can be concluded that the normality test in this study is normally distributed.

b) Multicollinearity Test

The multicollinearity test in this study used the help of the SPSS version 25 program with the test results in the following table:

\begin{tabular}{|l|l|l|l|}
\hline Variable & Tolerance & VIF & Description \\
\hline $\begin{array}{l}\text { Product } \\
\text { features }\end{array}$ & 0.544 & 1,838 & $\begin{array}{l}\text { There is no } \\
\text { multicollinearity }\end{array}$ \\
\hline $\begin{array}{l}\text { Product } \\
\text { quality }\end{array}$ & 0.544 & 1,838 & $\begin{array}{l}\text { There is no } \\
\text { multicollinearity }\end{array}$ \\
\hline
\end{tabular}

Source: Data processed by researchers, 2021

The results of the multicollinearity test above show that the product feature variable (X1) with a Tolerance value of 0.5440 .10 and VIF value of 1.83810 .00 , product quality (X2) with a Tolerance value of 0.5440 .10 and a VIF value of 1.83810 .00 . From the results, it can be concluded that in all independent variables there is no multicollinearity.

c) Heteroscedasticity Test

The results of this test are shown in the following table:

\begin{tabular}{|c|c|c|c|c|c|c|}
\hline \multirow{2}{*}{\multicolumn{2}{|c|}{ Model }} & \multicolumn{2}{|c|}{$\begin{array}{l}\text { Unstandardized } \\
\text { Coefficients }\end{array}$} & \multirow{2}{*}{$\begin{array}{c}\text { Standar } \\
\text { dized } \\
\text { Coeffici } \\
\text { ents } \\
\text { Beta }\end{array}$} & \multirow[t]{2}{*}{$\mathrm{t}$} & \multirow[t]{2}{*}{ Sig. } \\
\hline & & B & $\begin{array}{c}\text { Std. } \\
\text { Error }\end{array}$ & & & \\
\hline \multirow[t]{3}{*}{1} & (Constant) & 2.111 & 1,769 & & 1.193 & .236 \\
\hline & $\begin{array}{l}\text { product } \\
\text { features }\end{array}$ & -.016 & .087 & -.025 & -.182 & .856 \\
\hline & $\begin{array}{l}\text { product } \\
\text { quality }\end{array}$ & .037 & .086 & .059 & .429 & .669 \\
\hline
\end{tabular}

Source: Data processed by researchers, 2021

Based on the results of the Glejser test after the transformation of the data in the table above, the significance value of product features is 0.856 and the significance value of product quality is 0.699 , which means that the independent variable in this study has a significance value greater than 0.05 . That means in this study there is no indication of heteroscedasticity. 
The test results can be seen in the following table:

\begin{tabular}{|c|c|c|c|c|c|}
\hline \multirow[t]{2}{*}{ Model } & \multicolumn{2}{|c|}{$\begin{array}{l}\text { Unstandardized } \\
\text { Coefficients }\end{array}$} & \multirow{2}{*}{ 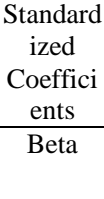 } & \multirow[t]{2}{*}{$\mathrm{T}$} & \multirow[t]{2}{*}{ Sig. } \\
\hline & B & $\begin{array}{l}\text { Std. } \\
\text { Error }\end{array}$ & & & \\
\hline (Constant) & 2,964 & 2.892 & & 1.025 & .308 \\
\hline $\begin{array}{l}\text { product } \\
\text { features }\end{array}$ & .520 & .141 & .189 & 2.848 & .008 \\
\hline $\begin{array}{l}\text { product } \\
\text { quality }\end{array}$ & .770 & .140 & .580 & 5.499 & .000 \\
\hline
\end{tabular}

Source: Data processed by researchers, 2021

Based on the results of multiple linear regression analysis in the table above, it can be seen that the multiple linear regression equation is as follows:

$y=2.964+0,520 x_{1}+0,770 x_{2}+\mathrm{e}$

The results of the multiple regression equation above can provide understanding as follows:

a) The constant value of 2,964 indicates that when the value of the independent variables, namely product features and product quality, is assumed to have a constant value equal to zero $(0)$, the value of the $\mathrm{Y}$ variable (brand switching) is 2,964 .

b) The regression coefficient value of the product feature variable is positive at 0.520 , which means that it is in the "positive" range. This value says that if the features of a product go up by one unit while other variables stay the same, the brand switching value will go up by 0.520 units.

c) The regression coefficient value of the product quality variable has a positive value of 0.770 . This value indicates that if the value of product quality increases by one unit while other independent variables are assumed to be constant, then the value of brand switching will increase by 0.770 units.

In this picture, you can see that the t-count for features of the products has been 2.848. This means that Ho isn't accepted because $\mathrm{t}$-count is greater than $\mathrm{t}$-table $(1,984)$. Ha is accepted. If $\mathrm{Ha}$ is accepted and $\mathrm{Ho}$ is not, it means that there is a significant effect. If $\mathrm{Ha}$ is accepted and Ho is not, it means that there is a significant effect. The fact that Ha was accepted and Ho has rejected means that the variable X1 (product features) has a big impact on $\mathrm{Y}$, which means that product features have a big impact on brand switching habits. It means that the $\mathrm{X} 1$ variable has a one-way relationship with Y. Because product features have a positive and significant effect on brand switching, it can be said that this is true.

It can be seen that the t-count value for the quality of the product is 5.499. This means that Ho isn't accepted because $\mathrm{t}$-count is greater than t-table $(1,984)$. Ha is accepted. If $\mathrm{Ha}$ is accepted and Ho is not, it means that there is a significant effect. If $\mathrm{Ha}$ is accepted and Ho is not, it means that there is a significant effect. The fact that $\mathrm{Ha}$ was accepted and Ho was rejected means that the variable X2 (product quality) has a big impact on $\mathrm{Y}$, which means that product quality has a big impact on brand switching habits. This means that the
$\mathrm{X} 2$ variable has a one-way relationship with Y. So, it can be said that the quality of a product has a positive and significant effect on brand switching.

\section{CONCLUSION}

Based on the explanation above, there are several conclusions, namely:

a) Based on research conducted on Eyeliner Implora users in Sumbawa City, it can be seen if the product feature variable has a significant and positive effect on the brand switching variable as evidenced by the t-test results in multiple linear regression analysis processed using the SPSS 25.0 program. Product features make an impact through size, ease of use, design, and quality of materials.

b) Based on research conducted on Eyeliner Implora users in Sumbawa City, it can be seen if the product quality variable has a significant and positive influence on brand switching behavior which is based on the results of the t-test on multiple linear regression analysis processed using the SPSS 25.0 program. Product quality influenced through form, performance quality, conformity quality, durability, reliability and perceived quality.

\section{SUGGESTION}

Based on all the theories and discussions of the previous test results, the suggestions that researchers can give to Implora are that Implora's cosmetics, especially Eyeliners, must further improve and multiply the features offered by their products both in terms of size, color variation and design and also improve the quality of previous products such as performance. , durability and shape. For researchers, it is hoped that they can continue to develop this research and deepen and apply marketing theory by adding variables that have not been studied in this study such as price variables, halal labels and promotions.

\section{REFERENCES}

1. Faustine, Megan. (2015). The Impact Of Variety Seeking, Social Status, Quality And Advertisement Towards Brand Switching In Smartphone Product (A Case Study Of Blackberry User Thas Has Ever Changed Into Another Smartphone Product In Surabaya). Ibuss Management, Vol 3, No 2, pp. 142-153.

2. Firmansyah, Anang. (2019). Product and Brand Marketing (Planning \& Strategy). Surabaya: Cv. Qiara Media Publisher.

3. Ghozali, Imam. (2018). "Application of Multivariate Analysis With SPSS Program". Semarang: Diponegoro University Publishing Agency.

4. Gujarati, DN (2012). Fundamentals of Econometrics, Mangunsong Translation, RC, Salemba Empat, book 2, Edition 5, Jakarta.

5. Hoffman \& Bateson. (2011). Service Marketing, International Edition 4e. Colorado State University: Cengage Learning.

6. Hawkins Delbert And David Mothersbaugh. (2016). Consumer Behavior, (13th Edition). McGraw-Hill.

7. Hoyer, Wayne D., Maclinnis, Deborah J., \& Pieters, Rik. (2012). Consumer Behavior: Sixth Edition. The USA. 
8. Kapojos, Januard R. (2017). Factors of Brand Switching Behavior: A Study on Employees Using Samsung Cell Phones at the Minahasa Regent's Office Tondano. Journal of Business and Management Research, Vol 5, No 4, pp 481-502.

9. Karen, Lay Yee., Kok Siew., \& Chan Yin Fah. (2013). Factors Affecting Smart-phone Purchase Decision Among Malaysian Generation Y. International Journal Of Asian Social Science, Vol 3, No 12. Hlm 2426-2440.

10. Kharis, Ismu Fadli. (2011). The Study of Impulse Buying in Online Sales. Thesis: Diponegoro University. Semarang

11. Khasanah, Aulia Uswatun \& Kuswati, Rini. (2013). Analysis of Factors Affecting Brand Switching on Smartphone Products. Benefit Journal of Management and Business, Vol 17, No 2, pp. 123-131.

12. Kotler, P. \& Armstrong, G. (2012). Marketing Management. Edition 13 Volume 2. Jakarta: Erlangga.

13. Kotler, P. \& Keller, L, K. (2013). Marketing Management. Edition 13 Volume 1. Jakarta: Erlangga.

14. Kotler and Keller, (2012). Marketing Management thirteenth edition, volumes 1 and 2 translated by Bob Sabran, Jakarta: Erlangga.

15. Kotler, Philip \& Kevin Lane Keller. (2009). Marketing Management. Translated by: Bob Sabran, Mm. Edition 13. Volume 2. Jakarta: Erlangga.

16. Meutia, Rahmi. (2017). Analysis of the Effect of Brand Image, Product Quality and Price on Brand Switching (Case Study on Oriflame Products in Langsa City). Journal of financial management, Vol 6, No 1. pp 770777.

17. Moorhead, Gregory \& Griffin, Ricky W. (2013). Organizational behavior: Human and Organizational Resource Management. Jakarta: Salemba Empat.

18. Mowen, John C and Minor, Michael. (2012). Consumer Behavior Translated by Dwi Kartika Yahya. Jakarta: Erlangga.

19. Nachrowi, Djalal Nachrowi \& Usman, Hardius. (2006). A popular and practical approach to econometrics for economic and financial analysis. Jakarta: University of Indonesia.

20. Oliver, Richard L. (2010). Satisfaction "A Behavior Perspective On The Consumer": Second Edition. USA: Routledge.

21. Peter, J Paul and Olson, JC (2014). Consumer Behavior And Marketing Strategy. Salemba Four.

22. Prasetya, Dimas. (2016). The Influence of Price Perception, Product Features and Word Of Mouth on Android Smartphone Purchase Decisions. Thesis: Yogyakarta State University.

23. Santoso, Singgih. (2010). Parametric Statistics, Concepts and Applications with SPSS. First Printing, PT Elex Media Komputindo, Jakarta, PT Gramedia.

24. Santoso, Singgih. (2012). SPSS Complete Guide Version 20. Jakarta: PT Elex Media Komputindo.

25. Sekaran, Uma and Bougie, R. (2017). Research Methods for Business Skills-Development Approach. Jakarta. Salemba Four.

26. Setiadi, Nugroho J. (2013). Revised Edition, Consumer Behavior: A Contemporary Perspective On Consumer Motives, Goals, and Desires. Jakarta: Kencana.

27. Sugiyono, (2019). "Statistics for Research". 30th Edition, Bandung: CV. Alphabet.

28. Suharno., \& Sutarso, Yudi. (2010). Marketing In Practice. Yogyakarta: Graha Ilmu.

29. Suswardji, Edi., Sungkono., Alfajri, Lutfi. (2012). The Influence of Product Attributes on Purchase Decisions for Suzuki Satria Fu Motorcycles (Case Study on Daeler Suzuki Sanggar Mas Jaya Karawang). Journal of Management, Vol.10 p. 1055-1069.

30. Tafiprios \& Astini, Rina. (2019). Brand Switching Behavior of Smartfren Cellular Phone Users. Scientific Journal of Management, Vol 9, No. 1, pp. 240-250.

31. Tjiptono, Fandy. (2012). Marketing strategy. Yogyakarta: PT Andi, Yogyakarta.

32. Wahyudi, Arinita Febrianti., et al. (2014). The Influence of Brand Image, Product Quality, and Price on Brand Switching (Study on Consumers of Implora Eyeliner Products in Jember Urban Area). 2014 student scientific articles. University of Jember.

33. Wijaya, Yoni Servika., Dh, Achmad Fauzi., \& Sunarti. (2014). The Influence of Product Attributes on Brand Switching Decisions (Survey on Students of the Faculty of Administrative Sciences Class of 2011/2012 Universitas Brawijaya Who Switched Brands to Samsung Smartphones). Journal of Business Administration, Vol 12, No 2.

34. Central Bureau of Statistics. (2016). Indonesia's 2016 Economic Census Chart.https://se2016.bps.go.id/umkumb/, accessed on September 2, 2019, at 21:50 WITA.

35. Jasaraharja Son. (2016). The Role of the Cosmetics \& Herbal Medicine Industry for the Indonesian Economy.https://www.jasaraharja-putera.co.id/peranindustri-kosmetik-jamu-bagi-perekonomian-indonesial, accessed on September 2, 2019, at 21:30 WITA.

36. Top Brand Awards. (2019).Top Brand Index.https://www.topbrand-award.com/, accessed on 19 October 2019 at 10:43 WITA.

37. Implora.(2019).ExclusiveLipstick.https://www.Implorabe auty.com/products/detail/exclusive-lipstick, accessed on September 20, 2019, at 20:00 WIB. 